\title{
Buying friends? The importance of economic flows in assembling the Iraq war coalition
}

\author{
Robert Riegler, Piotr Lis, Mehtap Hisarciklilar
}

August 29, 2017

\begin{abstract}
Economic ties between countries are likely to influence the alignment of their international policies. This paper investigates whether countries historical economic ties with the United States and their expectation of changes in future economic flows had a role in their decision to join the US-led coalition in Iraq from 2003 onwards. We use data on 115 countries over the period 2003-2009 to estimate panel random effects probit models of war coalition participation. We measure the intensity of economic ties with three variables: bilateral trade flows between the partner country and the US as well as FDI and aid flows from the US to the partner country. Our results suggest that both good trade relations prior to the conflict and the prospects of their further improvements increase the willingness of countries to join the coalition. In spite of the anecdotal evidence, we find no empirical evidence that the dependence on American FDI or aid affected countries decision on Iraq war participation.
\end{abstract}

\section{Introduction}

Economic flows between countries, such as trade, foreign direct investment (FDI) and foreign aid, can be important determinants of economic growth, job creation and good international political relations (Bandyopadhyay, Lahiri, and Younas, 2015, Jude and Silaghi, 2016, Nieman, 2016, Pandya, 2016). Thus, the intensity of economic ties is likely to influence the alignment of international policies, e.g. 
countries' decisions to support other states in international ventures, including military campaigns (Newnham, 2008).

This paper investigates whether previous economic ties with the United States (US) and the expectation of changes in bilateral economic flows influenced the probability of countries to join the US-led coalition in Iraq from 2003 onwards. Since the legitimacy of the war was not confirmed by the United Nations (UN), the US were likely to resort to using different tools to convince partners of shared interests and the benefits of war participation. These benefits, either of economic or political nature, were likely to be needed in order for the leaders of contributing nations to convince their electorates to accept sending troops in support of the USled campaign.

There is rich literature on theory of alliances in political economy (e.g. Kimball, 2006, Sprecher and Krause, 2006, Berkok, 2013, Arvanitidis, Kollias, and Messis, 2017), but less has been published on formation of ad-hoc war coalitions assembled for reasons other than reducing immediate and shared threats. Furthermore, the role of economic ties between countries at the coalition building stage is not well understood as the focus in the literature is placed on political factors. This is an oversight because one would expect economic factors to play a significant role; a potential coalition member may want to maintain an amicable relationship with a coalition leader who might be an important economic partner, ensure this partner of loyalty, maintain or boost economic ties, and in some cases avoid negative sanctions. This paper contributes to the literature by testing empirically the role of economic ties in states' decisions to join military coalitions.

\section{Previous work}

The discussion to date has been concentrated on political aspects of international relations in coalition building, while the economic factors have been largely neglected. Following Tago (2007), factors affecting incentives and disincentives for joining war coalitions can be divided into four groups: (i) system-level, (ii) dyad-level, (iii) state-level and (iv) operation-level. The first group relates to the relative power positions of countries and how they may shape benefits for secondtier states. The incentives of joining a coalition are positively influenced by a country's military capability, its major power status, colonial ties and geographic proximity to the theatre of war (Corbetta and Dixon, 2004, Tago, 2007, Vucetic, 2011, Corbetta, Volgy, and Rhamey, 2013).

The second group, the dyad-level factors, looks at similarities of cultural na- 
ture, which may give rise to common interests and thus augment the incentives to join a war coalition (Tago, 2007). The state-level factors refer to internal conditions within a potential coalition member, in particular its own security status, stability and involvement in internal or external disputes. A country facing severe security challenges of its own may be either constrained in contributing forces to a multinational coalition or willing to send a small contingent of troops to secure future economic or military aid from the US.

The operation-level category concerns the purpose and legitimacy of a coalition which are crucial for both persuading potential coalition member's domestic audience and assuring participation in the campaign (Tago, 2007, Vucetic, 2011). The US made numerous attempts to obtain the UN approval for the invasion of Iraq; having failed to secure it, far-going efforts were made to persuade wider international audiences of the war legitimacy (Breslow, 2016).

Most studies ignore economic interests of potential coalition participants. One of the few exceptions is a qualitative study by Newnham (2008) which presents an extensive review of examples of economic incentives in the form of economic and military aid, trade deals or sanctions, and investment used by the US to convince other states to join the "Coalition of the Willing" in Iraq to build the perception of international legitimacy for the mission. He concludes that side payments to states joining a coalition as well as threats of sanctions towards reluctant states can be an effective tool in assembling coalitions. A quantitative study by Vucetic (2011) points towards a limited impact of trade with the US on a decision to join a war coalition, in addition he finds no evidence that US aid could exert a similar impact. This finding is rather unexpected given the anecdotal evidence and the broad agreement in the aid literature that foreign assistance tends to be conditioned on donors' strategic considerations (buying policy concessions) rather than the recipients' needs; a tendency particularly pronounced since the War on Terror (Dreher, Nunnenkamp, and Thiele, 2008, Fleck and Kilby, 2010, Lis, 2014). As his focus was on political rather than economic variables, Vucetic (2011) does not show if pre-war economic ties and their changes will have an impact on the likelihood of joining a war coalition.

Our study aims to fill the existing gap in the literature and assess the role economic ties - in form of international trade, foreign military and economic aid, and additionally FDI - play in the process of forming war coalitions. 


\section{Method}

We assume that all countries other than the coalition leader and Iraq were candidates to join the US-led Multi-National Force - Iraq. We have data on FDI, trade and aid for 115 countries, including 30 countries which sent troops to Iraq over the period 2003 to $2009 .{ }^{1}$ We did not consider the last two years of the conflict (2010 and 2011) because only the United Kingdom remained as a coalition member. Table 1 summarises the data sources used.

Table 1: Data sources

\begin{tabular}{ll}
\hline \multicolumn{2}{c}{ Measures of bilateral economic ties } \\
Trade with the US (imports + exports) & IMF Direction of Trade Statistics \\
US outward FDI flows & Bureau of Economic Analysis (BEA) and OECD \\
Economic and military aid & U.S. Agency for International Development (2016) \\
& Political variables and controls \\
GDP per capita & World Bank World Development Indicators \\
Military expenditure & SIPRI (2017) \\
UN voting agreement & Bailey, Strezhnev, and Voeten (2017) \\
US ally & Gibler (2009) \\
Colonial relationship with US & GeoDist, Mayer and Zignago (2011) \\
Distance to Iraq & GeoDist, Mayer and Zignago (2011) \\
Level of Democracy & Center for Systemic Peace (2016) \\
\hline
\end{tabular}

All economic ties variables and military expenditure are divided by the GDP of the partner country.

Our dependent variable takes a value of one if a state contributed by sending troops to the war in Iraq and zero otherwise. We employ a panel random effects probit model to control for time-invariant country specific effects. We additionally include year dummies to capture trends that are common to all partner countries such as annual fluctuations in global conditions and/or changes in economic or political environment in the US. ${ }^{2}$

\footnotetext{
${ }^{1}$ The countries included in the coalition are: Albania, Australia, Azerbaijan, Bulgaria, Czech Republic, Denmark, Dominican Republic, El Salvador, Estonia, Honduras, Hungary, Italy, Japan, Kazakhstan, South Korea, Latvia, Netherlands, New Zealand, Nicaragua, Norway, Philippines, Poland, Portugal, Romania, Singapore, Slovakia, Spain, Thailand, Ukraine, United Kingdom. We do not have data on nine other coalition members: Armenia, Bosnia and Herzegovina, Georgia, Iceland, Lithuania, Macedonia, Moldova, Mongolia and Tonga.

${ }^{2}$ Inclusion of time dummies also minimises the potential risk of cross-country correlation in the errors.
} 
With respect to the explanatory variables, our main interest lies on measures of economic ties with the US. Firstly, we hypothesise that states that have stronger economic ties with the US prior to the war were more likely to contribute troops to the war effort. We measure the intensity of economic ties with bilateral trade flows, FDI inflows and foreign aid receipts from the US relative to the size of receiving country's GDP in year 2001. We choose 2001 as our reference period because the flows in 2002 may have been affected by the preparation to the invasion of Iraq and other campaigns in the War on Terror. Secondly, we would want to include countries' expectations of benefits in return for joining the war, which will be shaped by negotiations with the US. Unfortunately, those expectations are difficult to measure, as they tend to stay behind closed doors. However, we can observe materialised changes in economic flows. Assuming that the US fulfilled its promises, those actual flows can to some extent serve as a proxy of those expectations. ${ }^{3}$ Therefore, we introduce variables for measuring the difference in the level of economic flows between the current and the reference year. These differences ("buying friends" variables) measure the responsiveness of states to changes in the bilateral economic flows.

The choice of other control variables is dictated by findings of the studies discussed in the previous section. Our covariates at the (i) system-level are the share of a partner country's military expenditure to its GDP, colonial ties and the distance to Iraq; at the (ii) dyad-level are being a core English speaking country, being a US ally ${ }^{4}$ and the degree of similarity to the US in the UN voting behaviour; at the (iii) state-level are GDP per capita and a democracy indicator; and at the (iv) operation-level are dummies for capturing countries participating in the Afghanistan war and for countries which were members of the former Warsaw Pact. The last variable was added to capture countries which may have security concerns towards Russia. With the exception of distance to Iraq, we expect all other variables to show a positive relationship with the likelihood of joining the war coalition.

\footnotetext{
${ }^{3}$ Admittedly, this is a strong assumption. However, to be a credible partner for future ventures, it would be risky for the US not to fulfill its obligations.

${ }^{4} \mathrm{~A}$ dummy variable taking the value of one if a country was in a formal military alliance with the US in a given year and zero otherwise.
} 


\section{Results}

Table 2 presents the results for the periods $2003-2009$ and $2003-2006 .^{5}$ The second period was selected to show the impact of the covariates on the likelihood to participate in the first half of the conflict as well as to avoid the period of the financial crisis from 2007 onwards.

Table 2: RE Probit Results

\begin{tabular}{lcccc}
\hline Period & \multicolumn{2}{c}{$\mathbf{2 0 0 3}-\mathbf{2 0 0 9}$} & \multicolumn{2}{c}{$\mathbf{2 0 0 3}-\mathbf{2 0 0 6}$} \\
\hline Variable & Coeff. & Std. Err. & Coeff. & Std. Err. \\
\hline Trade/GDP 2001 & 8.55 & $(5.53)$ & $8.51^{*}$ & $(5.00)$ \\
Trade/GDP Difference & $18.80^{* *}$ & $(9.05)$ & $25.36^{* *}$ & $(12.09)$ \\
FDI/GDP 2001 & 33.98 & $(46.18)$ & 33.99 & $(31.78)$ \\
FDI/GDP Difference & -12.05 & $(11.86)$ & -14.30 & $(12.91)$ \\
Milit. Aid Oblig. 2001 & -406.50 & $(575.16)$ & 140.68 & $(517.47)$ \\
Milit. Aid Oblig./GDP Diff. & -255.89 & $(239.48)$ & -155.89 & $(262.64)$ \\
Econ. Aid Oblig. & -72.52 & $(75.66)$ & -70.79 & $(120.46)$ \\
Econ. Aid Oblig./GDP Diff. & $-249.27 * *$ & $(107.34)$ & -248.93 & $(162.90)$ \\
\hline GDP/Cap. in Thousands & 0.03 & $(0.05)$ & 0.03 & $(0.04)$ \\
Colony & $6.48^{* *}$ & $(2.23)$ & $3.63 *$ & $(2.03)$ \\
UN Agreement & 5.11 & $(6.72)$ & 1.85 & $(6.65)$ \\
ISAF & $7.73^{* *}$ & $(2.47)$ & $7.29 * * *$ & $(2.15)$ \\
Level of Democracy & 0.07 & $(0.13)$ & 0.05 & $(0.12)$ \\
Military Exp./GDP & $98.37 * *$ & $(38.19)$ & 27.58 & $(48.75)$ \\
Warsaw Pact & $12.68^{* * *}$ & $(2.28)$ & $10.76^{* * *}$ & $(1.98)$ \\
Anglosphere & 1.02 & $(3.13)$ & -1.28 & $(2.37)$ \\
US Ally & 2.33 & $(1.67)$ & $2.51^{*}$ & $(1.41)$ \\
Distance to Iraq (in km) & $0.0007^{* *}$ & $(0.0003)$ & $0.0004 *$ & $(0.0002)$ \\
Constant & $-21.65^{* * *}$ & $(3.67)$ & $-16.07 * * *$ & $(3.27)$ \\
\hline ln $\sigma_{v}^{2}$ & 3.68 & $(0.31)$ & 3.21 & $(0.36)$ \\
Observations & 684 & & 397 & \\
Time Dummies & Yes & & Yes & \\
\hline * & & & &
\end{tabular}

$* \mathrm{p}<0.1 ; * * \mathrm{p}<0.05 ; * * * \mathrm{p}<0.01$

\footnotetext{
${ }^{5}$ To check the robustness of results, six random effects panel probit regressions were estimated, spanning over various years of the war duration, i.e. starting from the time period $2003-2009$, then 2003 - 2008 until 2003 - 2004 (see Table 3 in the Appendix).
} 
The results indicate that a high level of bilateral trade with the US before the war was positively linked to the probability that a country would join the coalition. Furthermore, increases in trade share of GDP from its reference pre-war level also have a strongly significant positive association with the likelihood of being a coalition member. This finding is in line with Vucetic (2011).

FDI and military aid do not appear to have played a role in the decision whether to join the US-led coalition or not. Surprisingly, there is some indication of a negative relationship between changes in economic aid and sending troops to Iraq. This could be partly explained by the absence of African countries in Iraq, which are significant aid recipients and often experience domestic economic and security pressures of their own.

With respect to political drivers, we found evidence for the Warsaw Pact effect - states that belonged to the Soviet-controlled bloc during the Cold War were significantly more likely to join the Iraq war. This group constituted a large fraction of the coalition membership and accounted for 15 of 39 countries with military presence in Iraq. The Warsaw Pact effect is likely an attempt to mitigate risks linked to past and present security challenges. Many of the former Eastern bloc states that went to Iraq were intensively working on aligning themselves with the West and escaping the Russian zone of influence.

The coefficients in Table 2 also reveal that countries that were part of the ISAF task force in Afghanistan were more likely to join the Iraq war. As both campaigns were framed as a part of the War on Terror, involvement in Iraq could have been justified to the domestic electorate by arguing that this conflict was its continuation. Furthermore, the experience of military collaboration with the US would have facilitated the coordination and alignment of skills, experience and technology. Further results confirm the importance of existing military alliances when forming coalitions. The coefficient on distance to Iraq is positive and statistically significant which contradicts our initial hyporthesis. This result can be explained with the fact that none of the states from Iraq's neighbourhood decided to send troops to the country. This adds to the impression that participation in the war effort was likely to be driven by factors other than shared, direct and near security threats by coalition members.

Finally, we do not find sufficient evidence to confirm the importance of a country's military expenditure as a share of $\mathrm{GDP}^{6}$ or that of being a member of the Angloshphere in deciding whether to militarily assist the US in Iraq.

\footnotetext{
${ }^{6}$ Only in one out of six regressions we find a significant and positive impact of military expenditure. In shorter time panels this coefficient turns insignificant and negative.
} 
Overall, our results show that from the analysed types of economic flows only bilateral trade relations were likely to have a significant positive impact on forming the Iraq war coalition.

\section{Conclusions}

Our results suggest that the drivers of joining the US coalition were mainly of political nature, e.g. countries responding to past and present security conditions. From the economic ties variables, only bilateral trade with the US appeared to be positively associated with the probability of joining the coalition. Both good trade relations prior to the conflict and prospects of their further improvements appeared to have increased the willingness of countries to join the coalition. Thus, from the coalition leader's perspective, maintaining good trade relations in peace as well as conflict times appears to be the "buying friends" variable which may help to ensure support for military campaigns from other countries. In spite of the anecdotal evidence, there is no empirical evidence that the dependence on American FDI or aid affected countries' decisions on the participation in the Iraq war. Future research should consider the complementary side of the "buying friends" puzzle and investigate whether participation in the war translated into increased trade, investment or aid receipts between the US and the coalition members.

\section{References}

Arvanitidis, P., C. Kollias, and P. Messis (2017): “Converging allies?" Peace Economics, Peace Science and Public Policy, 23, 1-15.

Bailey, M. A., A. Strezhnev, and E. Voeten (2017): "Estimating dynamic state preferences from united nations voting data," Journal of Conflict Resolution, $61,430-456$.

Bandyopadhyay, S., S. Lahiri, and J. Younas (2015): "Financing growth through foreign aid and private foreign loans: Nonlinearities and complementarities," Journal of International Money and Finance, 56, 75-96.

Berkok, U. G. (2013): "Shape and consequences of military missions: An introduction,” Peace Economics, Peace Science and Public Policy, 19, 1-7. 
Breslow, J. M. (2016): “Colin Powell: U.N. speech was a great intelligence failure," Frontline, PBS.org.

Center for Systemic Peace (2016): Polity IV Project.

Corbetta, R. and W. J. Dixon (2004): "Multilateralism, major powers, and militarized disputes," Political Research Quarterly, 57, 5-14.

Corbetta, R., T. J. Volgy, and J. P. Rhamey (2013): "Major power status (in)consistency and political relevance in international relations studies," Peace Economics, Peace Science and Public Policy, 19, 291-307.

Dreher, A., P. Nunnenkamp, and R. Thiele (2008): "Does US aid buy UN general assembly votes? A disaggregated analysis," Public Choice, 136, 139 - 164.

Fleck, R. K. and C. Kilby (2010): "Changing aid regimes? U.S. foreign aid from the Cold War to the War on Terror," Journal of Development Economics, 91, 185-197.

Gibler, D. M. (2009): International Military Alliances, 1648-2008, Congressional Quarterly Press.

Jude, C. and M. I. P. Silaghi (2016): "Employment effects of foreign direct investment: New evidence from Central and Eastern European countries," International Economics, 145, 32-49.

Kimball, A. L. (2006): "Alliance formation and conflict initiation: The missing link," Journal of Peace Research, 43, 371-389.

Lis, P. (2014): "Terrorism, armed conflict and foreign aid," Peace Economics, Peace Science and Public Policy, 20, 655-667.

Mayer, T. and S. Zignago (2011): "Notes on cepiis distances measures: The geodist database," Working Papers 2011-25, CEPII, URL http://www . cepii.fr/CEPII/en/publications/wp/abstract. asp?NoDoc=3877.

Newnham, R. (2008): “Coalition of the bribed and bullied? U.S. economic linkage and the Iraq War Coalition,” International Studies Perspectives, 9, 183-200.

Nieman, M. D. (2016): "Moments in time: Temporal patterns in the effect of democracy and trade on conflict," Conflict Management and Peace Science, 33, 273-293. 
Pandya, S. S. (2016): "Political Economy of Foreign Direct Investment: Globalized production in the twenty-first century," Annual Review of Political Science, 19, 455-75.

SIPRI (2017): "Sipri military expenditure database," https://www.sipri.org/databases/milex.

Sprecher, C. and V. Krause (2006): “Alliances, armed conflict, and cooperation: Theoretical approaches and empirical evidence," Journal of Peace Research, 43, 363-369.

Tago, A. (2007): "Why do states join US-led military coalitions?: The compulsion of the coalition's missions and legitimacy," International Relations of the Asia-Pacific, 7, 179-202.

U.S. Agency for International Development (2016): "Foreign aid explorer: The official record of u.s. foreign aid," https://explorer.usaid.gov/data.html.

Vucetic, S. (2011): "Bound to follow? The Anglosphere and US-led coalitions of the willing, 1950-2001," European Journal of International Relations, 17, 27-49.

\section{A Appendix}




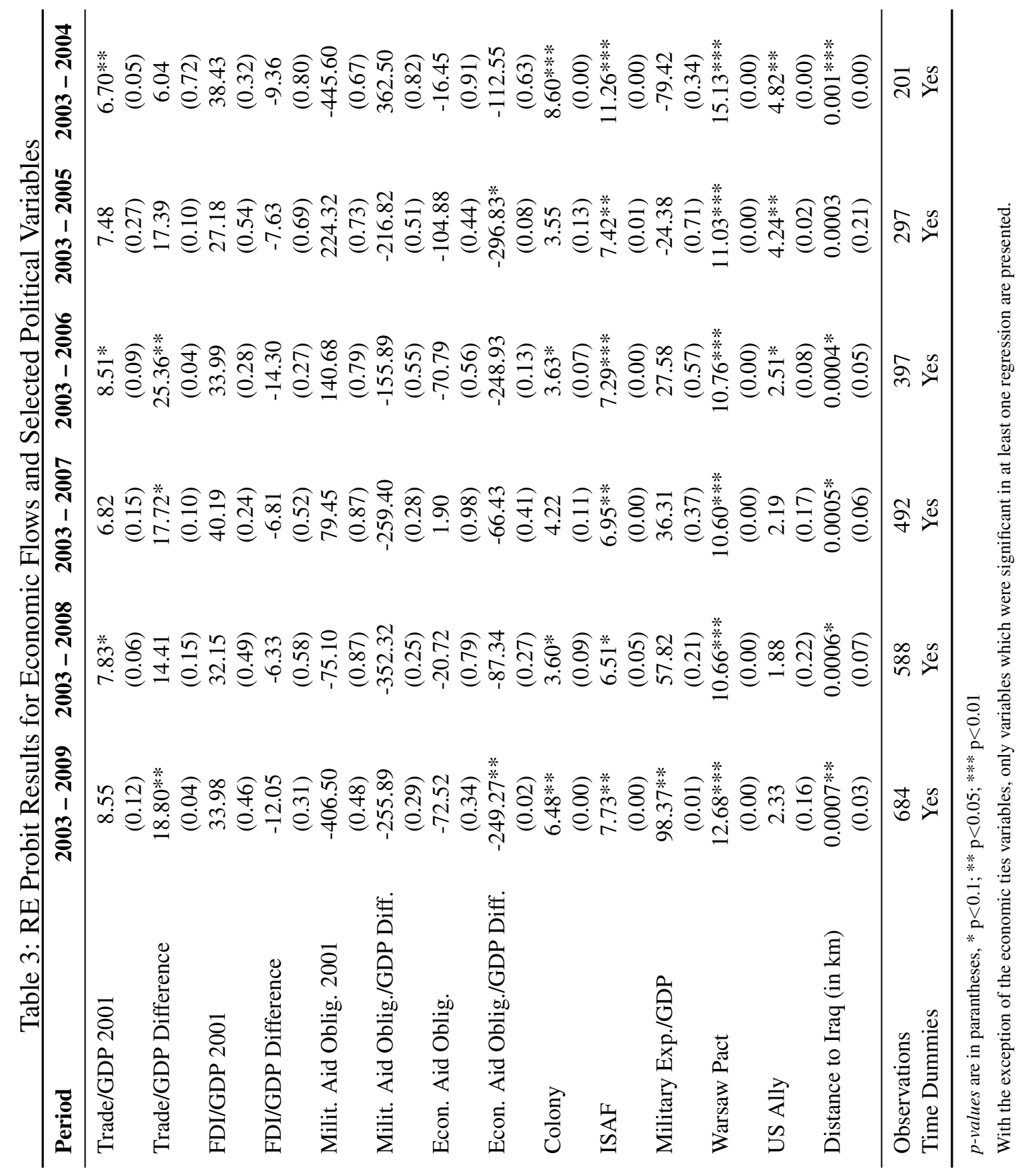

